\title{
Expression of Ki-67 Protein in Adenocarcinoma of Esophagogastric Junction and its Correlation with Clinicopathological Features and Prognosis
}

\author{
C. Y. WU, Z. R. HUANG*, R. P. CHEN AND W. P. LIN \\ Department of Thoracic Surgery, The First Affiliated Hospital of Guangdong Pharmaceutical University, No. 19, Nonglinxia \\ Road, Yuexiu District, Guangzhou 510006, China
}

Wu et al.: Expression of Ki-67 Protein in the Tissue of Adenocarcinoma

\begin{abstract}
In order to analyze the expression of nuclear-associated antigen Ki-67 protein in adenocarcinoma of esophagogastric junction and its correlation with clinicopathological features and prognosis, immunohistochemistry was used to detect the expression of nuclear-associated antigen Ki-67 protein in 165 tissues of adenocarcinoma of esophagogastric junction. The clinical data such as age, gender, tumor size, differentiation degree, pathological stage, TNM stage, lymphatic metastasis, surgical approaches and overall survival(OS) of 165 cases of adenocarcinoma of esophagogastric junction patients admitted to the First Affiliated Hospital of Guangdong Pharmaceutical University from January 2007 to June 2015 were analysed, retrospectively. Kaplan-Meier was used for univariate survival analysis and Cox regression was used for multivariate survival analysis to explore the independent risk factors for the prognosis of adenocarcinoma of esophagogastric junction. The value of $p<0.05$ was considered to be statistically significant. Over-expression of nuclear-associated antigen Ki-67 protein was found in $54.5 \%$ of primary adenocarcinoma of esophagogastric junction, which was related to the tumor size, lymphatic metastasis and recurrence and metastasis. The OS of the high expression group was lower than that of the low expression group. From the multivariate logistic regression analysis, the tumor differentiation (B: 0.912, OR: 0.402, OR $95 \%$ CI 0.199-0.810, $\mathrm{P}=0.011)$ and nuclear-associated antigen Ki-67 expression (B: 0.860, OR: 2.364, OR $95 \% \mathrm{CI}$ 1.145-4.881, $\mathrm{P}=\mathbf{0 . 0 2 0}$ ) were independent risk factors influencing the prognosis of adenocarcinoma of esophagogastric junction $(\mathbf{p}<\mathbf{0 . 0 5})$. The over-expression of nuclear-associated antigen Ki-67 plays a key role in the occurrence and development of adenocarcinoma of esophagogastric junction. It is an independent factor affecting the prognosis of adenocarcinoma of esophagogastric junction and provides theoretical support for the targeted treatment of adenocarcinoma of esophagogastric junction.
\end{abstract}

Key words: Ki-67, AEG, clinicopathological features, prognosis

During the past $30 \mathrm{y}$ the incidence of adenocarcinoma of esophagogastric junction (AEG) in the Western countries has been on the rise. According to the latest study of epidemiology in the United States, the incidence of AEG has increased by 5-10\% per year since the mid-1970 ${ }^{[1-3]}$. Since the growth position of AEG lies between the stomach and the esophageal fundus, the definition and classification of AEG have been controversial, thus clinical studies of AEG were relatively few. AEG was often classified as either gastric cancer or esophageal cancer, resulting in the lack of contrast between the results of relevant studies, so the best treatment for AEG is still unclear. At present, surgical eradication or chemo radiotherapy was usually used to treat AEG, but its prognosis was poor. Although the diagnostic and therapeutic techniques such as radical resection, chemotherapy or radiotherapy have been improved, many AEG patients often have recurrence and metastasis and the total survival time was still not optimistic $^{[4]}$.

Nuclear-associated antigen $\mathrm{Ki}-67$ (Ki-67) is a nonhistone in the nucleus, which was composed of two

*Address for correspondence

E-mail: gyhzr@126.com 
polypeptide chains and existed in the whole cell cycle. The expression of Ki-67 varies with the cell cycle, there was no expression in the G0 phase and it appeared in the middle to late phase of G1, increased gradually in the phase of S to G2, reached the peak in phase of M1 and degraded rapidly or lost antigenic determinant after phase M. Ki-67 was one of the most commonly used markers reflecting cell proliferation, and also the major focus of many researchers ${ }^{[5-7]}$.

In this study, immunohistochemistry was used to detect the expression of $\mathrm{Ki}-67$ protein in AEG, to explore its relationship with the biological behavior and clinicopathological characteristics of AEG and to provide a theoretical basis for the further study of the occurrence, development mechanism, and early treatment of AEG.

\section{MATERIALS AND METHODS}

\section{General data:}

The AEG and adjacent tissue samples were collected from First Affiliated Hospital of Guangdong Pharmaceutical University pathology from January 2007 to June 2017. With 130 males and 35 females, 79 cases were aged below 65 y, 86 cases were over 65 y. Ninety one cases of middle and high differentiation tumors, 74 cases of poorly differentiated (G3) tumors were grouped according to the degree of differentiation. One hundred and twenty-eight cases of stage I/II, 37 cases of stage III/IV were grouped according to TNM classification. Thirty cases of lymphatic metastasis more than 7, and 135 cases were less than 7 .

\section{Methods:}

The tissues were fixed in $10 \%$ neutral formalin solution, then dehydration, hyalinization, and embedded into paraffin wax. Each sample was made into 5 slices ( $4 \mu \mathrm{m})$, one for HE staining, 3 for immunohistochemical staining and the other kept as a standby. All the slices were stained by immunohistochemistry and HE. Antibodies were purchased from Abcam (Cambridge, UK). The slices were deparaffinized, antigen heat repaired by autoclave. The endogenous peroxidase activity was blocked with $3 \% \mathrm{H}_{2} \mathrm{O}_{2}$ and incubated with the first antibody at $4^{\circ}$ overnight. Then, the slices were washed with PBS for 3 times and incubated with polymerase adjuvant at $37^{\circ}$ for $20 \mathrm{~min}$, with HRP labelled goat antimouse $\operatorname{IgG}$ at $37^{\circ}$ for $30 \mathrm{~min}$. Color development of the slices was done with DAB solution, washed under running water, then re stained, dehydrated, hyalinized and mounted for microscopy.

\section{Result scoring:}

According to cell staining intensity score, colorless 0 , light yellow 1, medium yellow 2, brown yellow 3 and brown 4 . Five fields of vision were randomly selected under $100 \mathrm{X}$ magnification on a microscope and 100 cells were counted in each field. The average percent of positive cells in the 5 fields was counted as $0-100 \%$. The staining fraction was the product of the staining intensity and the percent positive cells, the total score was $0 \sim 400$ points. Patients were divided into 2 groups according to the average staining score of tumor samples, the high expression group with higher staining score of tumor samples and the low expression group with lower staining score.

\section{Statistical analysis:}

Statistical Software SPSS 22.0 was data analysis. The t-test was used for measurement data and the $\chi^{2}$ test was used for counting data. Kaplan-Meier was used for univariate survival analysis, Cox regression was used for multivariate survival analysis, the related variables and assignments were shown in (Table 1).

\section{RESULTS AND DISCUSSION}

In the 165 patients, there were 130 males and 35 females, 79 cases were aged below 65 y, 86 cases were over $65 \mathrm{y}$ old, with the median age at $67 \mathrm{y}$, RS (Range from 30-86 y old). Fifty eight cases of Siewert

\begin{tabular}{|c|c|c|}
\hline Factors & Variables & Assignment \\
\hline Gender & $\mathrm{X} 1$ & $0=$ female; $1=$ male \\
\hline Age & $x 2$ & $\begin{aligned} 0 & =\leq 65 \text { years old } \\
1 & =>65 \text { years old }\end{aligned}$ \\
\hline Tumor size & $\mathrm{X} 3$ & $0=\leq 5 \mathrm{~cm} ; 1=>5 \mathrm{~cm}$ \\
\hline $\begin{array}{l}\text { Classification of } \\
\text { tumors }\end{array}$ & $\mathrm{X} 4$ & $0=\mathrm{NET} ; 1=\mathrm{NEC} ; 2=\mathrm{MANEC}$ \\
\hline $\begin{array}{l}\text { Vessel/nerve } \\
\text { involvement }\end{array}$ & $\times 5$ & $0=$ No; $1=$ Yes \\
\hline Lymphatic metastasis & X6 & $0=$ No; $1=$ Yes \\
\hline TNM stage & $\mathrm{X} 7$ & $\begin{array}{c}0=\mathrm{I} / \mathrm{Il} \text { phase; } 1=\mathrm{III} / \mathrm{IV} \\
\text { phase }\end{array}$ \\
\hline $\begin{array}{l}\text { Recurrence and } \\
\text { metastasis }\end{array}$ & $x 8$ & $0=$ No; $1=$ Yes \\
\hline $\begin{array}{l}\text { Adjuvant } \\
\text { chemotherapy }\end{array}$ & X9 & $\begin{array}{c}0=\text { Not accepted; } \\
\text { 1=Accepted }\end{array}$ \\
\hline Survival time & $\mathrm{t}$ & Months \\
\hline
\end{tabular}


I, 52 cases of Siewert II and 55 cases of Siewert III were grouped according to the tumor site. One hundred and twenty-eight cases of stage I/II, 37 cases of stage III/IV were grouped according to TNM classification. Thirty cases with number of lymphatic metastasis more than 7 and 135 cases were less than 7 .

According to the dyeing strength ${ }^{[8,9]}$, the levels of $\mathrm{Ki}$ 67 were higher in AEG tumor (fig. 1), 165 cases of AEG were divided into the high expression group (90 cases) and low expression group (75 cases). The overall survival (os) curve of the 2 groups was shown in (fig. 2). In the 165 cases of the primary AEG tumor, the positive expression of $\mathrm{Ki}-67$ protein was related to the tumor size $(\mathrm{p}=0.002)$, lymphatic metastasis $(\mathrm{p}=0.030)$, recurrence and metastasis $(\mathrm{p}=0.019)$ and adjuvant chemotherapy $(p=0.014)$. And it was independent of tumor type, Siewert classification, histological differentiation, neurovascular invasion, and clinical staging $(\mathrm{p}=0.295)$, which were shown in (Table 2).

The 165 AEG patients were divided into the high Ki67 expression group and low Ki-67 expression group. There was a significant difference in the recurrence and metastasis between tumor differentiation and the expression of Ki-67 $(\mathrm{p}<0.05)$. And there was
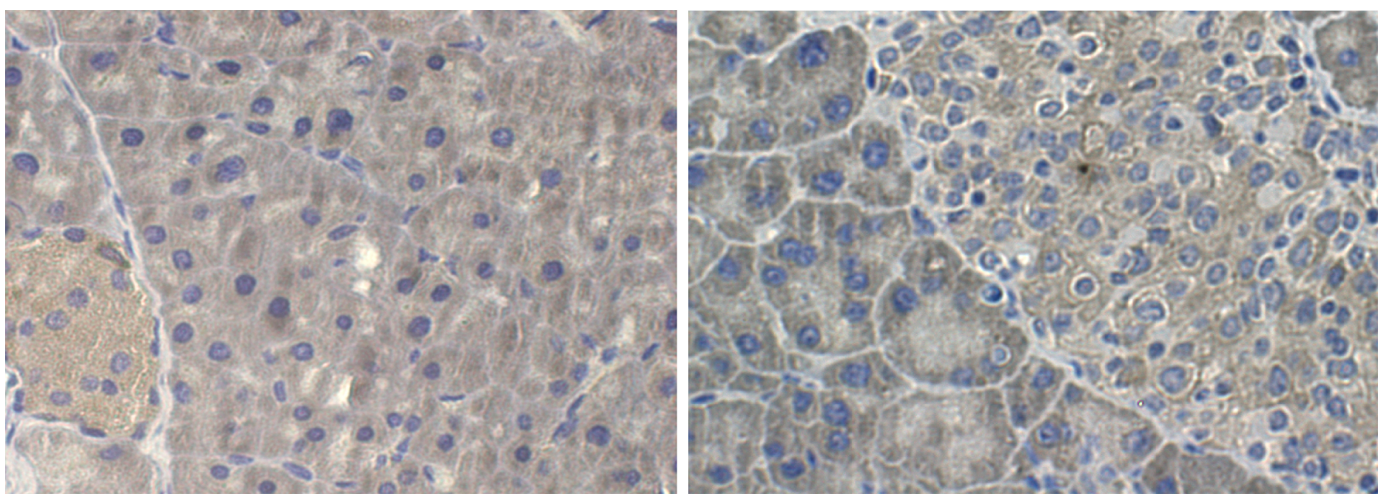

Fig. 1: Immunofluorescence staining of Ki-67 in the AEG tumor tissues

TABLE 2: RELATIONSHIP BETWEEN THE LEVEL OF Ki-67 PROTEIN AND CLINICOPATHOLOGICAL CHARACTERISTICS

\begin{tabular}{|c|c|c|c|c|c|}
\hline Factors & Cases (\%) & Low expression & High Expression & $\mathrm{X}^{2}$ value & $P$ value \\
\hline \multicolumn{6}{|l|}{ Gender } \\
\hline Female & $35(21.2)$ & $11(14.7)$ & $24(26.7)$ & 3.525 & 0.060 \\
\hline Male & $130(78.8)$ & $64(85.3)$ & $66(73.3)$ & & \\
\hline \multicolumn{6}{|l|}{ Age } \\
\hline$\leq 65$ & $79(47.8)$ & $37(49.3)$ & $42(46.7)$ & 0.117 & 0.733 \\
\hline$>65$ & $86(52.1)$ & $38(50.7)$ & $48(53.3)$ & & \\
\hline \multicolumn{6}{|l|}{ Tumor size } \\
\hline$\leq 4 \mathrm{~cm}$ & 79 (47.9) & $46(61.3)$ & $33(36.7)$ & 9.974 & 0.002 \\
\hline$>4 \mathrm{~cm}$ & $86(52.1)$ & $29(38.7)$ & $57(63.3)$ & & \\
\hline \multicolumn{6}{|l|}{ Tumor differentiation } \\
\hline Poorly differentiated & $74(44.8)$ & $33(44.0)$ & $41(45.6)$ & 0.040 & 0.841 \\
\hline Middle and high differentiation & $91(55.2)$ & $42(56.0)$ & $49(54.4)$ & & \\
\hline \multicolumn{6}{|l|}{ Siwert classification } \\
\hline I & $58(35.2)$ & $29(38.7)$ & $29(32.2)$ & 2.444 & 0.295 \\
\hline II & $52(31.5)$ & $19(25.3)$ & $33(36.7)$ & & \\
\hline III & $55(33.7)$ & $27(36.0)$ & $28(31.1)$ & & \\
\hline \multicolumn{6}{|l|}{ Vascular invasion } \\
\hline No & 84 (50.9) & $39(52.0)$ & $45(50.0)$ & 0.065 & 0.798 \\
\hline Yes & $81(49.1)$ & $36(48.0)$ & $45(50.0)$ & & \\
\hline
\end{tabular}

Lamellar sheath invasion 


\begin{tabular}{|c|c|c|c|c|c|}
\hline No & $83(50.3)$ & $36(48.0)$ & $47(52.2)$ & 0.292 & 0.589 \\
\hline Yes & $82(49.7)$ & $39(52.0)$ & $43(47.8)$ & & \\
\hline \multicolumn{6}{|l|}{ Lymphatic metastasis } \\
\hline$\leq 7$ & $135(81.8)$ & $56(74.7)$ & $79(87.8)$ & 4.727 & 0.030 \\
\hline$>7$ & $30(18.2)$ & $19(25.3)$ & $11(12.2)$ & & \\
\hline \multicolumn{6}{|l|}{ Surgical approaches } \\
\hline Radical resection of gastric cancer & $88(53.3)$ & $36(48.0)$ & $52(57.8)$ & 1.954 & 0.377 \\
\hline $\begin{array}{l}\text { Radical resection of cardiac } \\
\text { carcinoma }\end{array}$ & $74(44.8)$ & $38(50.7)$ & $36(40.0)$ & & \\
\hline Palliative resection & $3(1.8)$ & $1(1.3)$ & $2(2.2)$ & & \\
\hline \multicolumn{6}{|l|}{ TNM classification } \\
\hline I/II stage & $128(77.6)$ & $57(76.0)$ & $71(78.9)$ & 0.196 & 0.658 \\
\hline III/IVstage & $37(22.4)$ & $18(24.0)$ & $19(21.1)$ & & \\
\hline \multicolumn{6}{|l|}{ Postoperative complications } \\
\hline No & $144(87.3)$ & $62(82.7)$ & $82(91.1)$ & 2.626 & 0.105 \\
\hline Yes & $21(12.7)$ & $13(17.3)$ & $8(8.9)$ & & \\
\hline \multicolumn{6}{|l|}{ Recurrence and metastasis } \\
\hline No & $117(70.9)$ & $60(80.0)$ & $57(63.3)$ & 5.509 & 0.019 \\
\hline Yes & $48(29.1)$ & $15(20.0)$ & $33(36.7)$ & & \\
\hline \multicolumn{6}{|l|}{ Adjuvant chemotherapy } \\
\hline No & $109(66.1)$ & $57(76.0)$ & $52(57.8)$ & 6.059 & 0.014 \\
\hline Yes & $56(33.9)$ & $18(24.0)$ & $38(42.2)$ & & \\
\hline
\end{tabular}

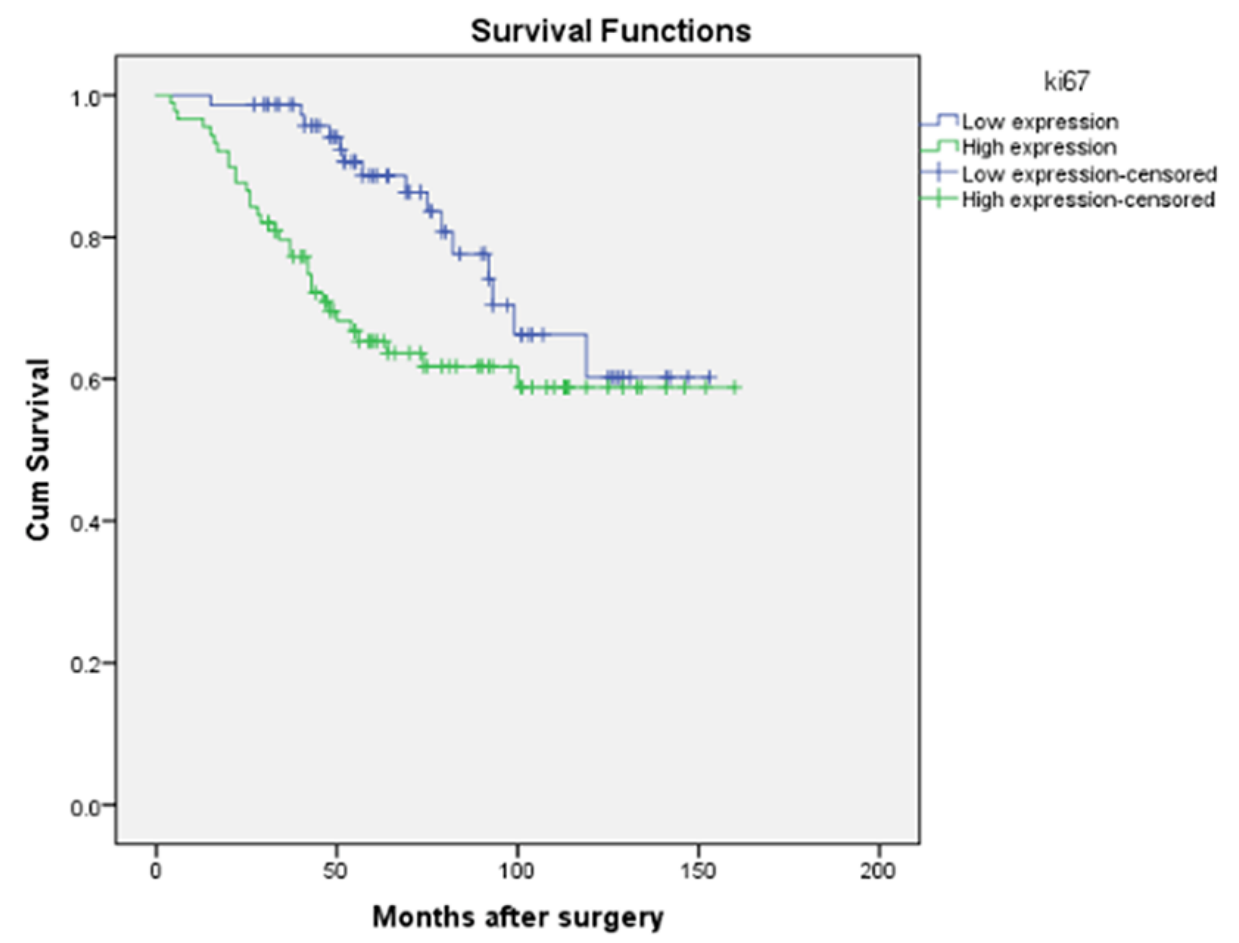

Fig. 2: OS survival curve of Ki-67 expression by univariate analysis

no significant difference in gender, age, Siwert According to the univariate analysis, tumor classification, neurovascular invasion, clinical stages, differentiation, the expression of Ki-67 was significantly surgical approaches, and adjuvant chemotherapy correlated with OS. The multivariate analysis showed ( $>0.05)$, which were shown in (Table 3). that Ki-67 expression (hazard ratio (HR) $=0.860,95 \%$ 
TABLE 3: UNIVARIATE ANALYSIS OF PROGNOSTIC FACTORS

\begin{tabular}{|c|c|c|c|c|c|}
\hline Factors & Cases (\%) & Survival & Death & $\mathrm{X}^{2}$ value & $P$ value \\
\hline \multicolumn{6}{|l|}{ Gender } \\
\hline Female & $35(21.2)$ & $24(20.5)$ & $11(22.9)$ & 0.118 & 0.732 \\
\hline Male & $130(78.8)$ & $93(79.5)$ & $37(77.1)$ & & \\
\hline \multicolumn{6}{|l|}{ Age } \\
\hline$\leq 65$ & $79(47.8)$ & $53(45.3)$ & $26(54.2)$ & 1.072 & 0.300 \\
\hline$>65$ & $86(52.1)$ & $64(54.7)$ & $22(45.8)$ & & \\
\hline \multicolumn{6}{|l|}{ Tumor size } \\
\hline$\leq 4 \mathrm{~cm}$ & 79 (47.9) & $54(46.2)$ & $25(52.1)$ & 0.480 & 0.489 \\
\hline$>4 \mathrm{~cm}$ & $86(52.1)$ & $63(53.8)$ & $23(47.9)$ & & \\
\hline \multicolumn{6}{|l|}{ Tumor differentiation } \\
\hline Poorly differentiated & $74(44.8)$ & $45(38.5)$ & $29(60.4)$ & 6.633 & 0.010 \\
\hline Middle and high differentiation & $91(55.2)$ & $72(61.5)$ & $19(39.6)$ & & \\
\hline \multicolumn{6}{|l|}{ Siwert classification } \\
\hline I & $58(35.2)$ & $41(35.0)$ & $17(35.4)$ & 0.208 & 0.901 \\
\hline II & $52(31.5)$ & $38(32.5)$ & $14(29.2)$ & & \\
\hline III & $55(33.7)$ & $38(32.5)$ & $17(35.4)$ & & \\
\hline \multicolumn{6}{|l|}{ Vascular invasion } \\
\hline No & $84(50.9)$ & $58(49.6)$ & $26(54.2)$ & 0.287 & 0.592 \\
\hline Yes & $81(49.1)$ & $59(50.4)$ & $22(45.8)$ & & \\
\hline \multicolumn{6}{|l|}{ Lamellar sheath invasion } \\
\hline No & $83(50.3)$ & $61(52.1)$ & $22(45.8)$ & 0.541 & 0.462 \\
\hline Yes & $82(49.7)$ & $56(47.9)$ & $26(54.2)$ & & \\
\hline \multicolumn{6}{|l|}{ Lymphatic metastasis } \\
\hline$\leq 7$ & $135(81.8)$ & $92(78.6)$ & $43(89.6)$ & 2.744 & 0.098 \\
\hline$>7$ & $30(18.2)$ & $25(21.4)$ & $5(10.4)$ & & \\
\hline \multicolumn{6}{|l|}{ Surgical approaches } \\
\hline Radical resection of gastric cancer & $88(53.3)$ & $63(53.8)$ & $25(52.1)$ & 1.846 & 0.397 \\
\hline Radical resection of cardiac carcinoma & $74(44.8)$ & $53(45.3)$ & $21(43.8)$ & & \\
\hline Palliative resection & $3(1.8)$ & $1(0.9)$ & $2(4.2)$ & & \\
\hline \multicolumn{6}{|l|}{ TNM classification } \\
\hline I/II stage & $128(77.6)$ & $87(74.4)$ & $41(85.4)$ & 2.392 & 0.122 \\
\hline III/IVstage & $37(22.4)$ & $30(25.6)$ & $7(14.6)$ & & \\
\hline \multicolumn{6}{|l|}{ Ki-67 } \\
\hline High & 90 & $71(60.7)$ & 19(39.6) & 5.509 & 0.019 \\
\hline Low & 75 & $46(39.3)$ & $29(60.4)$ & & \\
\hline \multicolumn{6}{|l|}{ Postoperative complications } \\
\hline No & $144(87.3)$ & $102(87.2)$ & $42(87.5)$ & 0.003 & 0.955 \\
\hline Yes & $21(12.7)$ & $15(12.8)$ & $6(12.5)$ & & \\
\hline \multicolumn{6}{|l|}{ Recurrence and metastasis } \\
\hline No & $75(45.5)$ & $60(51.3)$ & $15(31.3)$ & 5.509 & 0.019 \\
\hline Yes & $90(54.5)$ & $57(48.7)$ & $33(68.8)$ & & \\
\hline \multicolumn{6}{|l|}{ Adjuvant chemotherapy } \\
\hline No & $109(66.1)$ & $78(66.7)$ & $31(64.6)$ & 0.066 & 0.797 \\
\hline Yes & $56(33.9)$ & $39(33.3)$ & $17(35.4)$ & & \\
\hline
\end{tabular}

$\mathrm{CI}=1.145-4.881 ; \mathrm{p}=0.020$ was correlated with tumor differentiation, $\mathrm{HR}=0.912,95 \% \mathrm{CI}=0.199 \sim 0.810$; $\mathrm{p}=0.011$ in Cox proportional risk regression model (Table 4). The results suggest that Ki-67 and tumor differentiation may be the independent prognostic markers for primary AEG.
Esophagealcarcinoma,AEGand gastricadenocarcinoma were the most common cancers worldwide ${ }^{[9,10]}$. In addition, there has been a significant increase in the incidence of cancer at the gastroesophageal junction in the past decade, with gastroesophageal adenocarcinoma accounting for the vast majority of gastroesophageal 
www.ijpsonline.com

TABLE 4: MULTIVARIATE LOGISTIC REGRESSION ANALYSIS FOR PROGNOSIS (PREDICTIVE TRANSFER)

\begin{tabular}{lcccccccc}
\hline & B & $\begin{array}{c}\text { Standard } \\
\text { error }\end{array}$ & $\begin{array}{c}\text { Wald } \\
\text { Test }\end{array}$ & $\begin{array}{c}\text { Free } \\
\text { degree }\end{array}$ & Significance & Exp (B) & \multicolumn{2}{c}{ 95 confidence interval of EXP (B) } \\
\hline $\begin{array}{l}\text { Tumor } \\
\text { differentiation }\end{array}$ & 0.912 & 0.358 & 6.494 & 1 & 0.011 & 0.402 & 0.199 & 0.810 \\
$\begin{array}{l}\text { Expression of } \\
\text { Ki-67 }\end{array}$ & 0.860 & 0.370 & 5.410 & 1 & 0.020 & 2.364 & 1.145 & 4.881 \\
Constant & -0.937 & 0.331 & 8.039 & 1 & 0.005 & 0.392 & & Upper limit \\
\hline
\end{tabular}

junction cancers in East Asia ${ }^{[11,12]}$. Compared to other gastric cancers, AEG was more prone to deep invasion of the gastric wall, lymphatic metastasis, and postoperative recurrence. Besides, the prognosis of patients with these types of cancer was very poor ${ }^{[13,14]}$. Although in recent years, with the improvement of technology and the application of new drugs, the treatment of AEG has been improved to some extent, but its metastasis and recurrence was still an urgent problem that needed to be solved ${ }^{[15-17]}$. Therefore, discovering new treatment methods for AEG may provide new methods and hope for the treatment of cancer.

This retrospective study focused on the effect of the over-expression of $\mathrm{Ki}-67$ on the prognosis of AEG patients. The results showed that the expression of Ki67 was significantly different in tumor size, lymphatic metastasis, recurrence and metastasis $(p<0.05)$. In univariate analysis, there were significant differences in tumor differentiation and Ki-67 expression among different prognostic results $(\mathrm{p}<0.05)$. Cox regression analysis showed that $\mathrm{Ki}-67$ was an independent predictor of prognosis. To our knowledge, this is the first time to show that the high expression of Ki-67 status is associated with poor prognosis of AEG. The present data suggested that higher the expression of Ki-67, more likely the recurrence and metastasis were leading to worsening of prognosis. Therefore, these results suggested that Ki-67 was an important molecular marker for predicting the prognosis of AEG and a potential target for the treatment of AEG.

Ki-67 antigen was a nuclear antigen found in proliferating cells as reported by Gerdes et al. in $1983^{[18]}$ and it is also recognized as a nuclear proliferation marker. Ki-67, was also called Ki-67 antigen or MKI67. As a DNA binding protein, Ki-67 was mainly located in the nucleus and was related to the cell proliferation. Ki-67 has been widely used as one of the important markers of cell proliferation due to its presence in stationary cells (G0) but lack in G1 phase ${ }^{[19,20]}$. Ki-67 was one of the most common tumor prognostic markers ${ }^{[1-23]}$ and can also be used as a biomarker to identify high-risk individuals with precancerous lesions ${ }^{[24]}$. Poor prognosis of high $\mathrm{Ki}-67$ expression in tumor tissues ${ }^{[25,26]}$. In addition to traditional parameters, Ki-67 has been recommended as a key factor in tumor treatment decisions ${ }^{[27]}$. Many studies have found that the higher Ki-67 expression was associated with poor prognosis in breast cancer, prostate cancer, and some other cancers ${ }^{[23,28,29]}$. Interestingly, as an independent marker of colorectal cancer, higher Ki-67 expression was found to be associated with favourable clinical outcomes ${ }^{[30]}$. Previous studies have confirmed that the expression of Ki-67 was also correlated with the progression of colorectal cancer ${ }^{[31,32]}$, while the high expression of Ki-67 was associated with poor prognosis and severe differentiation of OSCC patients. These conflicting results could be partly due to the biological characteristics of various tumors.

Previous data have shown that the tumor proliferation activity was heterogeneous ${ }^{[33]}$. Tumor microenvironments containing multiple cells, such as matrix FLC, immune cells and endothelial cells, influence tumor progression through complex communication with $\mathrm{TC}^{[34]}$. Therefore, it is necessary to evaluate the expression of Ki-67 in hyper-proliferation regions. Low Ki-67 expression in Duke B colorectal cancer was associated with poor prognosis ${ }^{[32]}$. In addition, Ki-67 combined with HIF- $1 \alpha$ and CK20 can be used as a prognostic biomarker in colorectal cancer tissue microenvironment ${ }^{[35]}$. Therefore, the expression of tissue Ki-67 and its clinical prognosis were still uncertain.

Studies have shown that Ki-67 antigen was closely related to lung cancer, lumbar tumor, breast cancer, head and neck cancer, digestive tract tumor and might be associated with the occurrence, development, classification, staging, invasion, metastasis, recurrence, and prognosis of these tumors ${ }^{[22,24,36]}$. It can be used as a marker for diagnosis, prediction of curative effect, and prognosis. In this study, the high expression rate of Ki-67 antigen in AEG tissues was $54.5 \%$. The high 
expression of Ki-67 was significantly different in the size of the tumor, the number of lymphatic metastasis, recurrence and metastasis $(p<0.05)$. However, there was no significant difference in age, gender, tumor type, Siwert classification, clinical stage, surgical procedure and histological differentiation $(\mathrm{p}>0.05)$. At the same time, this study showed that there was significant difference in the survival curve of OS in patients with high or low Ki-67 expression. The Cox regression model was used to predict the factors related to recurrence and metastasis. The results showed that Ki-67 (HR=0.860, $95 \% \mathrm{CI}=1.145 \sim 4.881 ; \mathrm{p}=0.020)$ was an independent prognostic factor for primary AEG. These results suggested that $\mathrm{Ki}-67$ was related to the diagnosis and prognosis of oesophageal carcinoma. In conclusion, up-regulation of Ki-67 gene expression is closely related to the occurrence and development of AEG, which is helpful to evaluate the malignant degree and prognosis of AEG patients.

\section{Acknowledgements:}

Authors appreciate the support of the First Affiliated Hospital of Guangdong Pharmaceutical University.

\section{Conflict of interest:}

All authors report no conflicts of interest in this work.

\section{REFERENCES}

1. Bray F, Ferlay J, Soerjomataram I, Siegel RL, Torre LA, Jemal A, et al. Global cancer statistics 2018: GLOBOCAN estimates of incidence and mortality worldwide for 36 cancers in 185 countries. CA Cancer J Clin 2018;68:394-424.

2. Catenacci DVT, Tebbutt NC, Davidenko I, Murad AM, AlBatran SE, Ilson DH, et al. Rilotumumab plus epirubicin, cisplatin, and capecitabine as first-line therapy in advanced MET-positive gastric or gastro-oesophageal junction cancer (RILOMET-1): a randomised, double-blind, placebocontrolled, phase 3 trial. Lancet Oncol 2017;18:1467-82.

3. Thompson ED, Zahurak M, Murphy A, Cornish T, Cuka N, Abdelfatah E, et al. Patterns of PD-L1 expression and CD8 $\mathrm{T}$ cell infiltration in gastric adenocarcinomas and associated immune stroma. Gut 2017;66:794-801.

4. Sato Y, Katai H, Ito M, Yura M, Otsuki S, Yamagata Y, et al. Can proximal Gastrectomy Be Justified for Advanced Adenocarcinoma of the Esophagogastric Junction? J Gastric Cancer 2018;18:339-47.

5. Cuylen S, Blaukopf C, Politi AZ, Müller-Reichert T, Neumann B, Poser I, et al. Ki-67 acts as a biological surfactant to disperse mitotic chromosomes. Nature 2016;535:308-12.

6. Fasemore TM, Patzke N, Kaswera-Kyamakya C, Gilissen E, Manger PR, Ihunwo AO. The Distribution of Ki-67 and Doublecortin-Immunopositive Cells in the Brains of Three Strepsirrhine Primates: Galago demidoff, Perodicticus potto, and Lemur catta. Neuroscience 2018;372:46-57.

7. Wang XB, Lv GH, Li J, Zou MX. Ki-67 Index as a Prognostic Marker in Chordomas: A Systematic Review of the Literature.
World Neurosurg 2017;101:782-4.

8. Abubakar M, Howat WJ, Daley F, Zabaglo L, McDuffus LA, Blows F, et al. High-throughput automated scoring of Ki67 in breast cancer tissue microarrays from the Breast Cancer Association Consortium. J Pathol Clin Res 2016;2:138-53.

9. Abubakar M, Orr N, Daley F, Coulson P, Ali HR, Blows F, et al. Prognostic value of automated KI67 scoring in breast cancer: a centralised evaluation of 8088 patients from 10 study groups. Breast Cancer Res 2016;18:104.

10. Wong MCS, Hamilton W, Whiteman DC, Jiang JY, Qiao Y, Fung FD, et al. Global Incidence and mortality of oesophageal cancer and their correlation with socioeconomic indicators temporal patterns and trends in 41 countries. Sci Rep 2018;8:4522.

11. Sung JJ, Ng EK, Lin JT, Ho KY, Ji JF, Sugano K, et al. Digestive cancer management in Asia: position statements: a report on GI Oncology Summit in 2011. J Gastroenterol Hepatol 2012;27:1417-22.

12. Peng Z, Li Z, Gao J, Lu M, Gong J, Tang ET, et al. Tumor MET Expression and Gene Amplification in Chinese Patients with Locally Advanced or Metastatic Gastric or Gastroesophageal Junction Cancer. Mol Cancer Ther 2015;14:2634-41.

13. Gong EJ, Kim DH, Ahn JY, Jung KW, Lee JH, Choi KD, et al. Comparison of long-term outcomes of endoscopic submucosal dissection and surgery for esophagogastric junction adenocarcinoma. Gastric Cancer 2017;20:84-91.

14. Cancer Genome Atlas Research N: Comprehensive molecular characterization of gastric adenocarcinoma. Nature 2014;513:202-9.

15. Abe S, Ishihara R, Takahashi H, Ono H, Fujisaki J, Matsui A, et al. Long-term outcomes of endoscopic resection and metachronous cancer after endoscopic resection for adenocarcinoma of the esophagogastric junction in Japan. Gastrointest Endosc 2019; 89:1120-8.

16. Kudou K, Saeki H, Nakashima Y, Kamori T, Kawazoe T, Haruta $\mathrm{Y}$, et al. C-reactive protein/albumin ratio is a poor prognostic factor of esophagogastric junction and upper gastric cancer. J Gastroenterol Hepatol 2019;34:355-63.

17. Zhou YB, Yuan Y, Hu B, Che GW. Image of the Month: Primary Multifocal Malignant Melanoma of Esophagus CoOccurs With Esophagogastric Junction Adenocarcinoma. Am J Gastroenterol 2016;111:312.

18. Haroon S, Hashmi AA, Khurshid A, Kanpurwala MA, Mujtuba $\mathrm{S}$, Malik B, et al. Ki67 index in breast cancer: correlation with other prognostic markers and potential in pakistani patients. Asian Pac J Cancer Prev 2013;14:4353-8.

19. Ahmed ST, Ahmed AM, Musa DH, Sulayvani FK, Al-Khyatt M, Pity IS. Proliferative Index (Ki67) for Prediction in Breast Duct Carcinomas. Asian Pac J Cancer Prev 2018;19:955-9.

20. Green WJ, Ball G, Hulman G, Johnson C, Van Schalwyk G, Ratan HL, et al. KI67 and DLX2 predict increased risk of metastasis formation in prostate cancer-a targeted molecular approach. Br J Cancer 2016;115:236-42.

21. Miller I, Min M, Yang C, Tian C, Gookin S, Carter D, et al. Ki67 is a Graded Rather than a Binary Marker of Proliferation versus Quiescence. Cell Rep 2018;24:1105-12.

22. Zhou Y, Hu W, Chen P, Abe M, Shi L, Tan SY, et al. Ki67 is a biological marker of malignant risk of gastrointestinal stromal tumors: A systematic review and meta-analysis. Medicine 2017;96:e7911.

23. Melling N, Kowitz CM, Simon R, Bokemeyer C, Terracciano L, Sauter G, et al. High Ki67 expression is an independent good prognostic marker in colorectal cancer. J Clin Pathol 
2016;69:209-14.

24. Luporsi E, Andre F, Spyratos F, Martin PM, Jacquemier J, Penault-Llorca F, et al. Ki-67: level of evidence and methodological considerations for its role in the clinical management of breast cancer: analytical and critical review. Breast Cancer Res Treat 2012;132:895-915.

25. Luo ZW, Zhu MG, Zhang ZQ, Ye FJ, Huang WH, Luo XZ. Increased expression of $\mathrm{Ki}-67$ is a poor prognostic marker for colorectal cancer patients: a meta-analysis. BMC Cancer 2019;19:123.

26. Jing Y, Zhou Q, Zhu H, Zhang Y, Song Y, Zhang X, et al. Ki67 is an independent prognostic marker for the recurrence and relapse of oral squamous cell carcinoma. Oncol Lett 2019;17:974-80.

27. Huber AR, Tan D, Sun J, Dean D, Wu T, Zhou Z. High expression of carbonic anhydrase IX is significantly associated with glandular lesions in gastroesophageal junction and with tumorigenesis markers BMI1, MCM4 and MCM7. BMC Gastroenterol 2015;15:80.

28. Gao W, Wu J, Chen X, Lin L, Fei X, Shen K, et al. Clinical validation of $\mathrm{Ki} 67$ by quantitative reverse transcriptionpolymerase chain reaction (RT-PCR) in HR+/HER2- early breast cancer. J Cancer 2019;10:1110-6.

29. Fantony JJ, Howard LE, Csizmadi I, Armstrong AJ, Lark AL, Galet C, et al. Is Ki67 prognostic for aggressive prostate cancer? A multicenter real-world study. Biomark Med 2018;12:727-36.

30. Yang Z, Tang LH, Klimstra DS. Effect of tumor heterogeneity on the assessment of Ki67 labeling index in well-differentiated neuroendocrine tumors metastatic to the liver: implications for prognostic stratification. Am J Surg Pathol 2011;35:853-60.

31. Yang Y, Li J, Jin L, Wang D, Zhang J, Wang J, et al.
Independent Correlation Between Ki67 Index and Circulating Tumor Cells in the Diagnosis of Colorectal Cancer. Anticancer Res 2017;37:4693-700.

32. Li P, Xiao ZT, Braciak TA, Ou QJ, Chen G, Oduncu FS. Association between Ki67 Index and Clinicopathological Features in Colorectal Cancer. Oncol Res Treat 2016;39:696702.

33. Han L, Lam EW, Sun Y. Extracellular vesicles in the tumor microenvironment: old stories, but new tales. Mol Cancer 2019;18:59.

34. Jan AT, Rahman S, Khan S, Tasduq SA, Choi I. Biology, Pathophysiological Role, and Clinical Implications of Exosomes: A Critical Appraisal. Cells 2019;8:99.

35. Zhang $\mathrm{L}, \mathrm{Hu} \mathrm{Y}$, Xi N, Song J, Huang W, Song S, et al. Partial Oxygen Pressure Affects the Expression of Prognostic Biomarkers HIF-1 Alpha, Ki67, and CK20 in the Microenvironment of Colorectal Cancer Tissue. Oxid Med Cell Longev 2016;2016:1204715.

36. Liu Y, Yao X, Zhang Q, Qian L, Feng J, Bian T, et al. Expression of Kruppel-like factor 8 and Ki67 in lung adenocarcinoma and prognosis. Exp Ther Med 2017;14:1351-6.

This is an open access article distributed under the terms of the Creative Commons Attribution-NonCommercial-ShareAlike 3.0 License, which allows others to remix, tweak, and build upon the work non-commercially, as long as the author is credited and the new creations are licensed under the identical terms

This article was originally published in a special issue, "Biomedical applications in Pharmaceutical Sciences" Indian J Pharm Sci 2020:82(2)Spl issue3;127-134 